\title{
FITTINGS OF ADSORPTION ISOTHERM MODELS AND THERMODYNAMIC PROPERTIES OF URUNDAY SEEDS
}

\author{
Eder P. Isquierdo', Daniela S. A. Caldeira ${ }^{1}$, Valdiney C. Siqueira ${ }^{2}$, Elton A. S. Martins ${ }^{2}$, \\ Wellytton D. Quequeto ${ }^{3 *}$
}

$3^{3 *}$ Corresponding author. Instituto Federal de Educação, Ciência e Tecnologia Goiano/ Rio Verde - GO, Brasil.

E-mail: wellytton_quequeto@hotmail.com | ORCID: https://orcid.org/0000-0002-0658-2692

\begin{abstract}
KEYWORDS
water activity, isokinetic, sorption isotherms, Myracrodruon urundeuva, relative humidity.
\end{abstract}

\begin{abstract}
This study aimed to obtain and evaluate thermodynamic properties and hygroscopic equilibrium isotherms of urunday seeds as a function of air relative humidity and temperature, as well as identify the best-fitted mathematical models for adsorption phenomenon. A static-gravimetric method was used to obtain hygroscopic equilibrium moisture content. Seeds were placed in airtight containers with different saturated saline solutions for relative humidity control. These were then kept in BOD incubator chambers at 10, 20, 30, and $40{ }^{\circ} \mathrm{C}$. Hygroscopic equilibrium moisture content decreased as temperature increased, for the same water activity. The Sigma-Copace model best-fitted seed adsorption data for equilibrium water activity intervals between 0.1129 and 0.8232 (dry basis). Both vaporization latent-heat and differential sorption entropy increased with decreasing hygroscopic equilibrium moisture content. Adsorption process in urunday seeds was controlled by enthalpy.
\end{abstract}

\section{INTRODUCTION}

Urunday (Myracrodruon urundeuva Allem.) is a tree species native to Brazil, naturally distributed in its northeast, southeast, and midwest regions (CarmelloGuerreiro \& Paoli, 1999). It is a hardwood with characteristics such as hardness, elasticity, termite resistance, high density, long life, and excellent polishing, being valued in construction and furniture markets, as well as for fencing (Lorenzi, 2014). Besides, its bark can be used as tinting material (Carvalho, 2006), and its inner bark has anti-inflammatory and healing effects (Albuquerque et al., 2004).

Urunday has been exploited extractively and disorderly due to its properties and vast uses, with a strong impact on natural populations, compromising its preservation within natural habitats (Lima et al., 2017).

Conversely, a regular supply of quality seeds can favor urunday conservation, as germplasm conservation for future generations and success of forest plantations directly depend on the quality of seeds used for seedling production (Caldeira et al., 2012). In this sense, studies on seed storage conditions become essential to ensure viability and vigor for extended periods (Guedes et al., 2012).
Agricultural products in general, including seeds, undergo undesirable changes when stored, most often associated with their moisture content. Thus, each product behavior should be known under different temperature and relative humidity conditions to minimize oxidation, respiration, and growth of microorganisms (Labuza \& Altunakar, 2008).

Seeds tend to remain in balance with temperature and relative humidity conditions due to their hygroscopic characteristics. Such traits allow analysis through curves, known as sorption isotherms. For instance, these curves can be used to determine the relationship between a product moisture content and its water activity at a given temperature (Corrêa et al., 2014; Bustos-Vanegas et al., 2018; Zeymer et al., 2019).

Moreover, sorption isotherms enable calculation of some thermodynamic properties such as isosteric heat of sorption, as well as differential entropy and enthalpy. Determining these thermodynamic properties in drying processes of agricultural products (grains and seeds) is essential for designing equipment, calculating required energy, studying adsorbed water properties, besides evaluating microstructures and physical phenomena

\footnotetext{
${ }^{1}$ Universidade do Estado de Mato Grosso/ Cáceres - MT, Brasil.

${ }^{2}$ Universidade Federal da Grande Dourados/ Dourados - MS, Brasil.

Area Editor: Gizele Ingrid Gadotti

Received in: 4-18-2018

Accepted in: 3-13-2020
} 
occurring on the surface of such products (Oliveira et al., 2014; Campos et al., 2019).

Therefore, this study was carried out to characterize and evaluate thermodynamic properties, as well as determining and modeling hygroscopic equilibrium isotherms of urunday seeds, and identifying the mathematical models best fitting water adsorption phenomenon.

\section{MATERIAL AND METHODS}

Seeds of urunday (Myracrodruon urundeuva) were acquired from a commercial establishment in the city of Cáceres in Mato Grosso State (Brazil). They originated from northwestern São Paulo State (Brazil) and were processed by Arbocenter Comércio de Sementes in 100-g packages, with an initial moisture content of $0.04 \mathrm{~g} \mathrm{~g}^{-1}(\mathrm{db})$. A static-gravimetric method was used to determine hygroscopic equilibrium moisture content.

Samples of $3 \pm 0.2 \mathrm{~g}$ seeds were placed into airtight containers, totaling three replications. These seeds were surrounded by an inert and permeable fabric (voile) for free passage of air.

Air temperature and relative humidity were monitored using a digital thermo-hygrometer, with a probe inserted into the airtight containers.

Different saturated saline solutions were used to control environmental conditions inside the airtight containers with seeds, which were submitted to controlled temperatures $\left(10,20,30\right.$, and $\left.40{ }^{\circ} \mathrm{C}\right)$ in $\mathrm{BOD}$ incubator chambers (Table 1).

TABLE 1. Relative air humidity (\%) as a function of saturated solutions and temperatures used to determine hygroscopic equilibrium.

\begin{tabular}{lcccc}
\hline & \multicolumn{3}{c}{ Temperature $\left({ }^{\circ} \mathrm{C}\right)$} \\
\cline { 2 - 5 } & Saturated saline solution & 10 & 20 & 30 \\
\hline Lithium chloride & 11.29 & 11.31 & 11.28 & 11.21 \\
Potassium carbonate & 43.14 & 43.16 & 43.17 & 43.17 \\
Magnesium nitrate & 57.36 & 54.38 & 51.40 & 48.42 \\
Potassium iodide & 72.11 & 69.90 & 67.89 & 66.09 \\
Potassium chloride & 86.77 & 85.11 & 83.62 & 82.32 \\
\hline
\end{tabular}

Equilibrium moisture content was determined by weighing the samples every 24 hours. Hygroscopic equilibrium was reached when the mass remained unchanged after two consecutive weighings. Then, seed moisture content was determined in an oven at $105{ }^{\circ} \mathrm{C}$ for $24 \mathrm{~h}$ (Brasil, 2009).

Mathematical models used to describe hygroscopicity of agricultural products were fitted to equilibrium moisture content data for urunday seeds, whose expressions are shown in Table 2.

TABLE 2. Models used to verify the behavior of adsorption isotherms of urunday seeds.

\begin{tabular}{llc}
\hline \multicolumn{1}{c}{ Model } & \multicolumn{1}{c}{ Equation } & Reference \\
\hline Chung Pfost & $\mathrm{X}_{\mathrm{e}}=\mathrm{a}-\mathrm{b}\left[-(\mathrm{T}+\mathrm{c}) \ln \left(\mathrm{a}_{\mathrm{w}}\right)\right]$ & Chung \& Pfost et al. (1967) \\
Copace & $\mathrm{X}_{\mathrm{e}}=\exp \left[\mathrm{a}-(\mathrm{bT})+\left(\mathrm{ca}_{\mathrm{w}}\right)\right]$ & Corrêa et al. (1995) \\
Modified Henderson & $\mathrm{X}_{\mathrm{e}}=\left\{\ln \left(1-\mathrm{a}_{\mathrm{w}}\right) /[(-\mathrm{aT}+\mathrm{b}]\}^{1 / \mathrm{c}}\right.$ & Henderson $(1952)$ \\
Oswin & $\mathrm{X}_{\mathrm{e}}=(\mathrm{a}-\mathrm{bT}) /\left[\left(1-\mathrm{a}_{\mathrm{w}}\right) / \mathrm{a}_{\mathrm{w}}\right]^{1 / \mathrm{c}}$ & Oswin $(1945)$ \\
Sabbab & $\mathrm{X}_{\mathrm{e}}=\mathrm{a}\left(\mathrm{a}_{\mathrm{w}} \mathrm{b} / \mathrm{T}^{\mathrm{c}}\right)$ & ASAE (2003) \\
Sigma-Copace & $\mathrm{X}_{\mathrm{e}}=\exp \left\{\mathrm{a}-(\mathrm{bT})+\left[\mathrm{c} \exp \left(\mathrm{a}_{\mathrm{w}}\right)\right]\right\}$ & Corrêa et al. $(1995)$ \\
\hline
\end{tabular}

Where:

$\mathrm{Xe}$ is the product moisture content $(\mathrm{db})$;

$\mathrm{a}_{\mathrm{w}}$ is the water activity (decimal);

$\mathrm{T}$ is the ambient air temperature $\left({ }^{\circ} \mathrm{C}\right)$;

$\mathrm{T}_{\text {abs }}$ is the absolute ambient air temperature $(\mathrm{K})$, and

$\mathrm{a}, \mathrm{b}$, and $\mathrm{c}$ are the product nature parameters.

The mathematical models were fitted using nonlinear regression analyses by the Gauss-Newton method, through STATISTICA 7.0 ${ }^{\circledR}$ software.

Experimental data were compared with estimates from each model for representativeness. To this end, a chisquare test $\left(\chi^{2}\right)$ was applied, and coefficient of determination
$\left(\mathrm{R}^{2}\right)$, relative mean error $(\mathrm{P})$, and estimated mean error $(\mathrm{SE})$ were estimated using eqs (10), (11) and 12, respectively.

$$
\begin{aligned}
& \chi^{2}=\sum\left(\frac{Y-\widehat{Y}}{D F}\right)^{2} \\
& P=\frac{100}{n} \sum_{i=1}^{n}\left(\frac{|Y-\widehat{Y}|}{Y}\right) \\
& S E=\sqrt{\frac{\sum_{i=1}^{n}(Y-\widehat{Y})^{2}}{D F}}
\end{aligned}
$$

Where:

$\mathrm{n}$ is the number of experimental observations;

$\mathrm{Y}$ is the experimental value;

$\hat{\mathrm{Y}}$ is the model estimate, and

$\mathrm{DF}$ is the degree of freedom of the model. 
According to Mohapatra \& Rao (2005), relative mean error is a parameter used to recommend or reject a model. Relative mean errors reflect observed value deviations relative to the model estimated curve (Kashaninejad et al., 2007). Estimated mean error, on the other hand, demonstrates a model's ability to describe a particular physical process accurately; the lower its value, the better the model-fit quality regarding experimental data (Siqueira et al., 2012).

Net isosteric sorption heat (or differential enthalpy) was calculated for each equilibrium moisture content using the Clausius-Clayperon expression (Iglesias \& Chirife 1976):

Where:

$$
\frac{\partial \ln \left(\mathrm{a}_{\mathrm{w}}\right)}{\partial \mathrm{T}}=\frac{\Delta \mathrm{h}_{\mathrm{st}}}{\mathrm{RT}_{\mathrm{a}}^{2}}
$$

$\mathrm{T}_{\mathrm{a}}$ is the absolute temperature $(\mathrm{K})$;

$\Delta \mathrm{h}_{\text {st }}$ is the net isosteric sorption heat $\left(\mathrm{kJ} \mathrm{kg}^{-1}\right)$, and

$\mathrm{R}$ is the universal gas constant $\left(8,314 \mathrm{~kJ} \mathrm{kmol}^{-1} \mathrm{~K}^{-1}\right)$ for water vapor of $0.4619 \mathrm{~kJ} \mathrm{~kg}^{-1} \mathrm{~K}^{-1}$.

Integrating [eq. (13)] and assuming that the net isosteric sorption heat is independent of temperature, this value was obtained for each equilibrium moisture content according to [eq. (14)] (Wang \& Brennan, 1991):

Where:

$$
\ln \left(\mathrm{a}_{\mathrm{w}}\right)=-\left(\frac{\Delta \mathrm{h}_{\mathrm{st}}}{\mathrm{R}}\right) \cdot \frac{1}{\mathrm{~T}_{\mathrm{a}}}+\mathrm{C}
$$

$\mathrm{C}$ is the model coefficient.

Water activity, temperature, and equilibrium moisture content were obtained from adsorption isotherms of urunday seeds. And integral isosteric sorption heat was obtained by summing net isosteric sorption heat and freewater vaporization latent-heat, as in [eq. (15)]:

$$
\mathrm{Q}_{\mathrm{st}}=\Delta \mathrm{h}_{\mathrm{st}}+\mathrm{L}
$$

Where:

$\mathrm{Q}_{\text {st }}$ is the integral isosteric sorption heat $\left(\mathrm{kJ} \mathrm{kg}^{-1}\right)$, and

$\mathrm{L}$ is the vaporization latent-heat of free water $(\mathrm{kJ}$ $\left.\mathrm{kg}^{-1}\right)$.

The free-water vaporization latent-heat $\left(\mathrm{L}, \mathrm{kJ} \mathrm{kg}^{-1}\right)$, which is required for calculation of $\mathrm{Q}_{\mathrm{st}}$, was obtained by the mean temperature $\left(\mathrm{T},{ }^{\circ} \mathrm{C}\right)$ of the range under study, according to [eq. (16)]:

$$
\mathrm{L}=2502.2-2.39 \mathrm{~T}
$$

Differential sorption entropy was calculated from the Gibbs-Helmholtz equation (Rizvi, 1995), as in [eq. (17)]:

Where:

$$
\Delta \mathrm{S}=\frac{\Delta \mathrm{h}_{\mathrm{st}}-\Delta \mathrm{G}}{\mathrm{T}_{\mathrm{a}}}
$$

$\Delta \mathrm{S}$ is the differential sorption entropy $\left(\mathrm{kJ} \mathrm{kg}^{-1} \mathrm{~K}^{-1}\right)$, and

$\Delta \mathrm{G}$ is the Gibbs free energy $\left(\mathrm{kJ} \mathrm{kg}^{-1}\right)$.
Gibbs free energy was calculated using [eq. (18)]:

$$
\Delta \mathrm{G}=\mathrm{R} \cdot \mathrm{T} \cdot \ln \left(\mathrm{a}_{\mathrm{w}}\right)
$$

The effects of changes in water sorption on free energy are usually accompanied by changes in enthalpy and entropy values. Thus, replacing [eq. (18)] in (17) and rearranging, we have [eq. (19)]:

$$
\ln =\frac{\Delta \mathrm{h}_{\mathrm{st}}}{\mathrm{R} \cdot \mathrm{T}_{\mathrm{a}}}-\frac{\Delta \mathrm{S}}{\mathrm{R}}
$$

The calculated values of differential enthalpy $\left(\Delta \mathrm{h}_{\mathrm{st}}\right)$ and entropy $(\Delta S)$ of sorption were correlated by [eq. (20)] (Beristain et al., 1996):

$$
\Delta \mathrm{h}_{\mathrm{st}}=\mathrm{T}_{\mathrm{B}}(\Delta \mathrm{S})+\Delta \mathrm{G}_{\mathrm{B}}
$$

Where:

$\mathrm{T}_{\mathrm{B}}$ is the isokinetic temperature $(\mathrm{K})$, and

$\Delta \mathrm{G}_{\mathrm{B}}$ is the Gibbs free energy at isokinetic temperature $\left(\mathrm{kJ} \mathrm{kg}^{-1}\right)$.

The isokinetic temperature was compared with the harmonic mean temperature used to determine sorption isotherms to confirm the existence of compensation and determine the control of the process by enthalpy or entropy, according to [eq. (21)]:

$$
\mathrm{T}_{\mathrm{hm}}=\frac{\mathrm{n}}{\sum\left(\frac{1}{\mathrm{~T}}\right)}
$$

Where:

$\mathrm{T}_{\mathrm{hm}}$ is the harmonic mean temperature $(\mathrm{K})$, and

$\mathrm{n}$ is the number of used temperatures.

According to Krug et al. (1976), linear chemical compensation or compensation theory only exists if the isokinetic temperature $\left(T_{B}\right)$ is different from the harmonic mean temperature $\left(\mathrm{T}_{\mathrm{hm}}\right)$. An approximate confidence interval of $(1-\alpha) 100 \%$ for isokinetic temperature was calculated by the following equation:

$$
\mathrm{T}_{\mathrm{B}}=\widehat{\mathrm{T}} \pm \mathrm{t}_{\mathrm{m}-2, \alpha / 2 \sqrt{\operatorname{Var}\left(\mathrm{T}_{\mathrm{B}}\right)}}
$$

Where:

$$
\widehat{\mathrm{T}}_{\mathrm{B}}=\frac{\sum\left(\Delta \mathrm{h}_{\mathrm{St}}-\overline{\Delta \mathrm{h}_{\mathrm{St}}}\right)(\Delta \mathrm{S}-\overline{\Delta \mathrm{S}})}{\sum(\Delta \mathrm{S}-\overline{\Delta \mathrm{S}})^{2}}
$$

and

$$
\operatorname{Var}\left(\mathrm{T}_{\mathrm{B}}\right)=\frac{\sum\left(\Delta \mathrm{h}_{\mathrm{st}}-\overline{\Delta \mathrm{G}_{\mathrm{B}}}-\widehat{\mathrm{T}}_{\mathrm{B}} \Delta \mathrm{S}\right)^{2}}{(\mathrm{~m}-2) \sum(\Delta \mathrm{S}-\overline{\Delta \mathrm{S}})^{2}}
$$

Where:

$\mathrm{m}$ is the number of enthalpy and entropy data pairs;

$\overline{\Delta \mathrm{h}_{\mathrm{st}}}$ is the mean enthalpy $\left(\mathrm{kJ} \mathrm{kg}^{-1}\right)$, and

$\overline{\Delta \mathrm{S}}$ is the mean entropy $\left(\mathrm{kJ} \mathrm{kg}^{-1}\right)$.

In the verification of the enthalpy-entropy linear isokinetic, if $T_{B}>T_{h m}$, the process is controlled by enthalpy, otherwise $\left(T_{B}<T_{h m}\right)$ the process is controlled by entropy; if $\mathrm{T}_{\mathrm{hm}}$ is in the isokinetic temperature range, it is considered an experimental error (Corrêa et al., 2012). 


\section{RESULTS AND DISCUSSION}

Table 3 shows that only the Sigma-Copace model exhibited a reduced relative mean error, below 10\%. Therefore, the deviation can be considered acceptable. Also, this model was the one that stood out the most for having the smallest SEs compared to the others.

TABLE 3. Coefficients of models fitted to hygroscopic equilibrium moisture contents of urunday seeds, with their respective coefficients of determination $\left(\mathrm{R}^{2}, \%\right)$, estimated error (SE, decimal), and relative mean error (P, \%), as well as chi-square test $\left(\chi^{2}\right)$.

\begin{tabular}{lccccccc}
\hline \multirow{2}{*}{ MODEL } & \multicolumn{3}{c}{ COEFFICIENT } & \multirow{2}{*}{$\mathrm{R}^{2}$} & $\mathrm{P}$ & $\mathrm{SE}$ & $\mathrm{X}^{2}$ \\
\cline { 2 - 5 } & $\mathrm{A}$ & $\mathrm{B}$ & $\mathrm{C}$ & & & & \\
\hline CHUNG PFOST & 0.2989 & 0.04910 & 65.2245 & 94.29 & 15.09 & 0.0164 & 0.00027 \\
SABBAB & 0.2462 & 0.95855 & 0.0859 & 87.27 & 22.76 & 0.0241 & 0.00058 \\
COPACE & -3.3046 & 0.00376 & 1.9479 & 96.12 & 11.55 & 0.0136 & 0.00018 \\
OSWIN & 0.0005 & -0.000003 & 0.0170 & 38.78 & 48.22 & 0.0455 & 0.00207 \\
MODIFIED HENDERSON & 0.1122 & 746.072 & 0.1122 & 85.58 & 24.68 & 0.0255 & 0.00065 \\
SIGMA-COPACE & -4.1475 & 0.00340 & 1.0761 & 97.88 & 8.53 & 0.0100 & 0.00010 \\
\hline
\end{tabular}

The chi-square test showed that all models were within 95\% confidence interval, but when comparing magnitudes, the Sigma-Copace model had the lowest value. Low chi-square values show the better fit of a model (Siqueira et al., 2012).

The coefficients of determination of the models Sabbab, Oswin, and Modified Henderson were below 88\%, and the other models had CVs above $94 \%$. Despite being an additional analysis, in this case, the highest $\mathrm{CV}$ of the Sigma-Copace model reinforces its good fit to the data.

Among all tested models, Sigma-Copace stood out and met statistical parameters and hence selected for prediction of the hygroscopic balance of urunday seeds. Similar and satisfactory results were also obtained for this model in crambe fruits (Costa et al., 2015), Barbados nut seeds (Chaves et al., 2015), and Bahia rosewood and angico seeds (Mesquita Basílio et al., 2015).

The isotherms in Figure 1 show the good fit of the Sigma-Copace model to urunday seed hygroscopic balance. We noticed that as temperature increased moisture content decreased at a constant water activity. Besides, as water activity increased at a constant temperature, equilibrium moisture content tended to increase as well. Most agricultural products follow this same behavior. Once the Sigma-Copace model is fundamentally exponential, there is no isotherm inflection to predict moisture contents when water activity tends to zero, which limits this model to a restricted water activity range of urunday seeds.

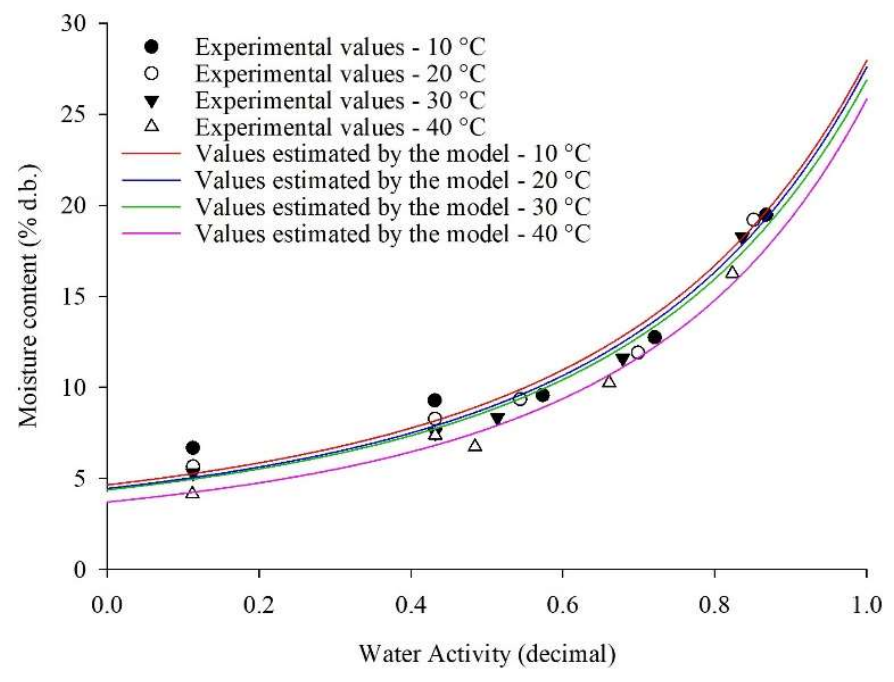

FIGURE 1. Experimental and estimated values by the Sigma-Copace model for hygroscopic equilibrium of urunday seeds under different temperature and water activity conditions

Figure 2 shows the experimental and estimated values of integral isosteric heat of adsorption (A), differential sorption entropy (B), and linear enthalpy-entropy relationship (C) as a function of the equilibrium moisture content of urunday seeds. 
A.

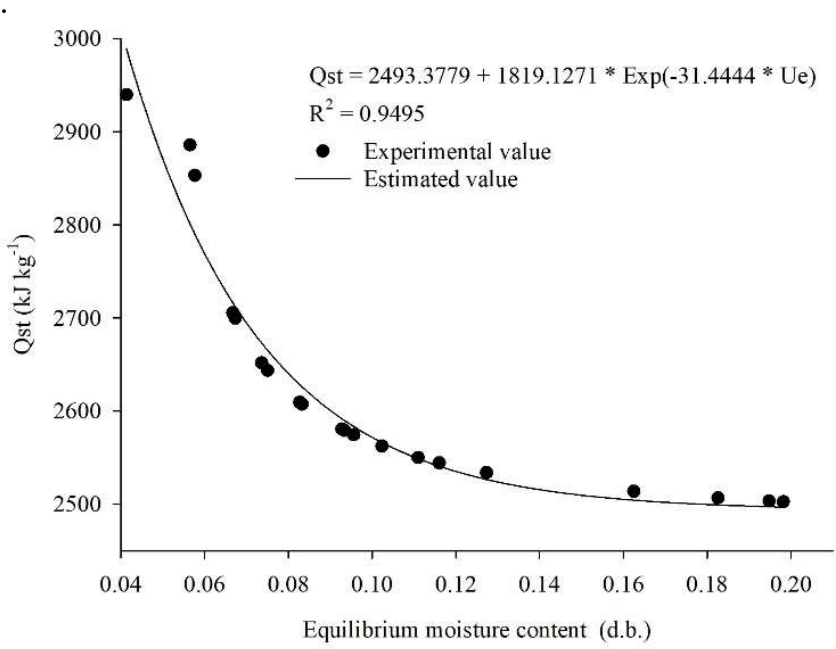

C.

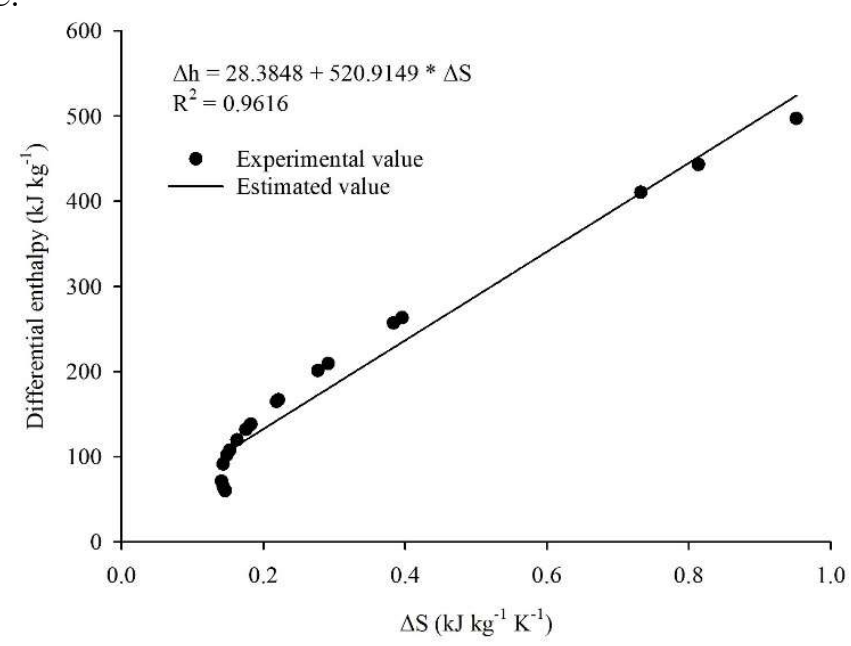

B.

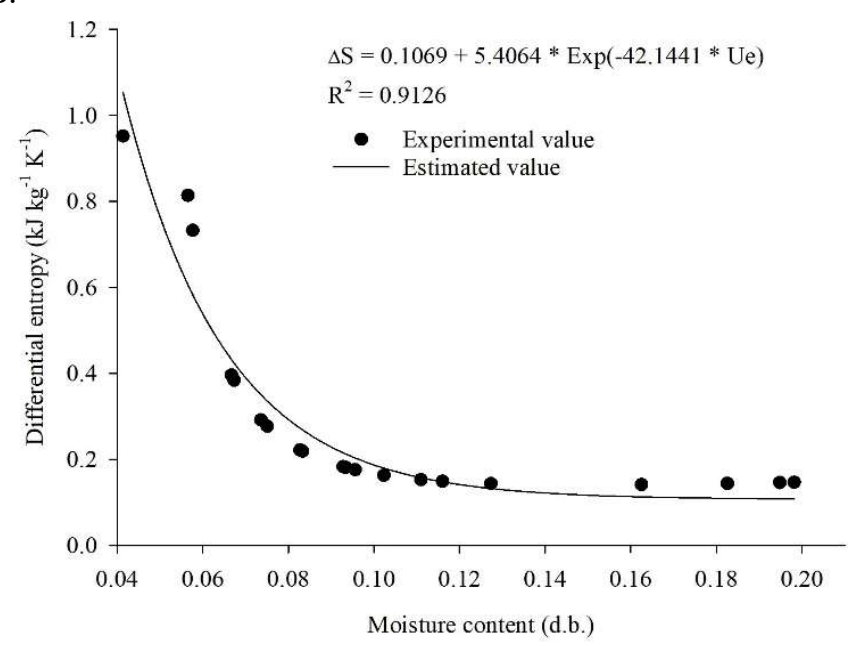

FIGURE 2. Experimental and estimated values of integral isosteric sorption heat (A), differential sorption entropy (B), and linear enthalpy-entropy relationship (C) for sorption process as a function of equilibrium moisture content

Figure $2 \mathrm{~A}$ shows that the lower the moisture content, the higher the energy to remove water from the product, which is represented by integral isosteric sorption heat $\left(\mathrm{Q}_{\mathrm{st}}\right)$. Other researchers have already observed such behavior for several other agricultural products, such as Coffea canephora fruits (Corrêa et al., 2014), baru fruits (Resende et al., 2017), pequi diaspores (Sousa et al., 2016), and butternut pumpkin seeds (Teixeira et al., 2018). It occurs because a higher amount of energy is needed compared to that required for wetter products, so that water could be removed from seeds with low moisture content (Brooker et al., 1992).

Differential entropy and enthalpy were strongly related to seed moisture content (Figure 2B) because there is a marked decrease in differential entropy as moisture content increases, with a trend to stabilize at high moisture contents. Goneli et al. (2010) described this behavior with okra seeds, showing that a high-water activity led to fewer sites available for bonds between molecules, resulting in decreased mobility of water molecules.

The isokinetic theory for water adsorption of urunday seeds can be considered valid based on the good fit of the linear regression for the relationship between differential enthalpy and differential entropy (Figure 2C).

The validity of the enthalpy-entropy isokinetic theory is tested by comparing the isokinetic temperature
$\left(T_{B}\right)$ with the harmonic mean temperature $\left(T_{h m}\right)$ of the studied range, used to determine the desorption process in urunday seeds.

The isokinetic temperature for water desorption was $520.91 \mathrm{~K}$, ranging from 563.58 to $478.25 \mathrm{~K}$. The calculated harmonic mean was $297.73 \mathrm{~K}$, which was different from the described isokinetic temperatures, confirming enthalpyentropy compensation and showing that enthalpy controls the process. These results are in line with those of other studies by several researchers, who used the isokinetic theory for different agricultural products (Oliveira et al., 2014; Sousa et al., 2015; Silva et al., 2015; Resende et al., 2017; Corrêa et al., 2017).

\section{CONCLUSIONS}

The hygroscopic equilibrium moisture content of urunday seeds increased with increasing water activity but decreased with increasing temperature at a constant water activity.

The Sigma-Copace model can be used to describe adsorption isotherms of urunday seeds.

Both vaporization latent-heat and differential sorption entropy increased with decreasing hygroscopic equilibrium moisture contents.

Enthalpy controls the adsorption process in urunday seeds. 


\section{REFERENCES}

Albuquerque RJM, Rodrigues LV, Viana GSB (2004) Análise clínica e morfológica da conjuntivite alérgica induzida por ovalbumina e tratada com chalcona em cobaias. Acta Cirúrgica Brasileira 19(1):43-68.

ASAE - Agricultural Engineers Yearbook of Standards (2003) American Society of Agricultural Engineers.

Beristain CI, Garcia HS, Azuara E (1996) Enthalpyentropy compensation in food vapor adsorption. Journal of Food Engineering 30(3-4):405-415. DOI: http://dx.doi.org/10.1016/S0260-8774(96)00011-8

Brasil (2009) Ministério da Agricultura e Reforma Agrária. Secretaria Nacional de Defesa Agropecuária. Regras para Análise de Sementes. Brasília, Secretaria Nacional de Defesa Agropecuária, 398 p.

Brooker DB, Bakker-Arkema FW, Hall CW (1992) Drying and storage of grains and oilseeds. Westport, The AVI Publishing, 450p.

Bustos-Vanegas JD, Corrêa PC, Zeymer JS, Baptestini FM, Campos RC (2018) Moisture sorption isotherms of quinoa seeds: thermodynamic analysis. Engenharia Agrícola 38(6):941-950. DOI:

http://dx.doi.org/10.1590/1809-4430-

eng.agric.v38n6p941-950/2018

Caldeira MV, Gomes DR, Gonçalves EO, Delarmelina WM, Sperandio HV, Trazzi PA (2012) Biossólido como substrato para produção de mudas de Toona ciliata var. australis. Revista Árvore 36:1009-1017.

Campos RC, Correa PC, Zaidan IR, Zaidan ÚR, Leite RA (2019) Moisture sorption isotherms of sunflower seeds: Thermodynamic analysis. Ciência e Agrotecnologia, 43(1)1-12. DOI: http://dx.doi.org/10.1590/14137054201943011619

Carmello-Guerreiro SM, Paoli AAS (1999) Aspectos morfológicos anatômicos da semente de aroeira (Myracrodruon urundeuva Fr. Allem. - Anacardiaceae), com notas sobre paquicalaza. Revista Brasileira de Sementes 21(1):222-228.

Carvalho PER (2006) Espécies arbóreas brasileiras. Embrapa florestas, p.97-104.

Chaves TH, Resende O, Oliveira DEC, Smaniotto TAS, Sousa KA (2015) Isotermas e calor isostérico das sementes de pinhão-manso. Engenharia na agricultura 23(1):9-18. DOI: http://dx.doi.org/10.13083/ 14143984/reveng.v23n1p9-18

Chung DS, Pfost HB (1967) Adsorption and desorption of water vapors by cereal grains and their products and Part II: development of the general isotherm equation. Transactions of the ASAE 10(1):549-551. DOI: http://dx.doi.org/10.13083/10.13031/2013.39727

Corrêa PC, Martins DSR, Melo EC (1995) Umigrãos: programa para o cálculo do teor de umidade de equilíbrio para os principais produtos agrícolas. Viçosa, Centreinar, $10 \mathrm{p}$.
Corrêa PC, Oliveira GHH, Santos ES (2012)

Thermodynamic properties of agricultural products processes. In: Arana I (org.). Physical properties of foods: Novel measurement techniques and applications. CRC Press, p.131-141.

Corrêa PC, Botelho FM, Botelho SDC, Goneli ALD (2014) Sorption isotherms of fruits of Coffea canephora. Revista Brasileira de Engenharia Agrícola e Ambiental 18(10):1047-1052.

DOI: http://dx.doi.org/10.1590/18071929/agriambi.v18n10p1047-1052

Corrêa PC, Baptestini FM, Vanegas JD, Leite R, Botelho FM, Oliveira GH (2017) Kinetics of water sorption of damaged bean grains: Thermodynamic properties. Revista Brasileira de Engenharia Agrícola e Ambiental 21(8):556561. DOI: http://dx.doi.org/10.1590/18071929/agriambi.v21n8p556-561

Costa LM, Resende O, Oliveira DEC (2015) Determinação das isotermas de equilíbrio higroscópico de frutos de crambe pelo método dinâmico. Bioscience Journal 31(2):382-391. DOI: http://dx.doi.org/10. 14393/BJv31n2a2015-22337

Goneli ALD, Corrêa PC, Oliveira GD, Botelho FM (2010) Water desorption and thermodynamic properties of okra seeds. Transaction of the ASAE 53(1):191-197. DOI: $10.13031 / 2013.29486$

Iglesias H, Chirife J (1976) Prediction of the effect of temperature on water sorption isotherms of food material. Journal of Food Technology 11(2):109-116. DOI: https://doi.org/10.1111/j.1365-2621.1976 tb00707

Guedes RS, Alves EU, Bruno RLA, Gonçalves EP, Costa EG Medeiros MS (2012) Armazenamento de sementes de Myracrodruon urundeuva Fr. All. em diferentes embalagens e ambientes. Revista Brasileira de Plantas Medicinais, 14(1):68-75. DOI: http://dx.doi.org/10.1590/S1516-05722012000100010.

Henderson SM (1952) A basic concept $f$ equilibrium moisture content. Agricultural Engineering 33(1):29-31.

Kashaninejad M, Mortazavi A, Safekordi A, Tabil LG (2007) Thin-layer drying characteristics and modeling of pistachio nuts. Journal of Food Engineering 78(1):98-108. DOI: https://doi.org/10.1016/j.jfoodeng.2005.09.007

Krug RR, Hunter WG, Grieger RA (1976) Enthalpyentropy compensation. 1 - Some fundamental statistical problems associated with the analysis of Van't Hoff and Arrhenius data. Journal of Physical Chemistry 80(21):2335-2341. DOI: http://dx.doi.org/10.1021/j100562a006

Labuza TP, Altunakar B (2008) Water activity prediction and moisture sorption isotherms. In: Barbosa-Cánovas GV, Fontana AJ, Schmidt SJ, Labuza TP (eds). Water activity in foods: Fundamentals and aplplications. Blackwell Publishing, p. 109-154.

Lima LKS, Moura MCF, Santos CC, Nascimento KPC, Dutra AS (2017) Produção de mudas de aroeira-do-sertão (Myracrodruon urundeuva Allemão) em resíduos orgânicos. Revista Ceres 64 (1):001-011. DOI: http://dx.doi.org/10.1590/0034-737x201764010001. 
Lorenzi H (2014) Árvores brasileiras: manual de identificação e cultivo de plantas arbóreas nativas do Brasil. Nova Odessa, Plantarum, 6 ed. 368p.

Mesquita Basílio J, Andrade ET, Corrêa PC (2015) Mathematical models and curves of equilibrium moisture content of seeds of jacaranda-da-bahia, angico vermelho and óleo-copaíba. Cerne 7(2):012-021.

Mohapatra D, Rao PSA (2005) Thin layer drying model of parboiled wheat. Journal of Food Engineering 66(4):513518, 2005. DOI:

http://dx.doi.org/10.1016/j.jfoodeng.2004.04.023

Oliveira DEC, Resende O, Chaves TH, Souza KA, Smaniotto TAS (2014) Propriedades termodinâmicas das sementes de pinhão-manso. Bioscience Journal 30(3):147-157.

Oswin CR (1945) The kinetics of package life III. The isotherm. Journal of Chemical Industry 65(1):419-421. DOI: http://dx.doi.org/10.1002/jctb.5000651216

Resende O, Oliveira DEC, Costa LM, Júnior F, Weder N (2017) Thermodynamic properties of baru fruits (Dipteryx alata Vogel). Engenharia Agrícola 37(4):739-749. DOI: http://dx.doi.org/10.1590/1809-4430eng.agric.v37n4p739-749/2017

Rizvi SSH (1995) Thermodynamic properties of foods in dehydration. In: Rao MA, Rizvi SSH (eds). Engineering properties of foods. Academic Press, p. 223-309.

Silva CLOC, Faria LJG, Costa CML (2015)

Comportamento higroscópico de partes aéreas de pimentade-macaco (Piper aduncum L.). Revista Brasileira de Engenharia Agrícola e Ambiental 19(4):376-381. DOI: http://dx.doi.org/10.1590/1807-

1929/agriambi.v19n4p376-381
Siqueira VC, Resende O, Chaves TH (2012)

Determination of the volumetric shrinkage in jatropha seeds during drying. Acta Scientiarum. Agronomy 34(3):231-238. DOI: http://dx.doi.org/10.4025 /actasciagron.v34i3.14402

Sousa KA, Resende O, Goneli ALD, Smaniotto TAS, Oliveira DEC (2015) Thermodynamic properties of water desorption of forage turnip seeds. Acta Scientiarum. Agronomy 37(1):11-19. DOI: http://dx.doi.org/10.4025/actasciagron.v37i1.19333

Sousa KAD, Resende O, Carvalho BDS (2016) Determination of desorption isotherms, latent heat and isosteric heat of pequi diaspore. Revista Brasileira de Engenharia Agrícola e Ambiental 20(5):493-498. DOI: http://dx.doi.org/10.1590/18071929/agriambi.v20n5p493-498

Teixeira LP, Andrade ETD, Devilla IA (2018) Isosteric heat, entropy, and gibbs free energy of pumpkin seeds (Cucurbita moschata). Engenharia Agrícola 38(1):97-102. DOI: http://dx.doi.org/10.1590/1809-4430eng.agric.v38n1p97-102/2018

Wang N, Brennan JG (1991) Moisture sorption isotherm characteristics of potato at four temperatures. Journal of Food Engineering 14:269-287.

Zeymer JS, Corrêa PC, Oliveira GH, Baptestini FM, Campos RC (2019) Mathematical modeling and hysteresis of sorption isotherms for paddy rice grains. Engenharia Agrícola 39(4):524-532. DOI: https://doi.org/10.1590/1809-4430-eng.agric.v39n4p524$532 / 2019$ 